\title{
Energising Mexico: Historical Energy Consumption, Transitions and Economic Growth 1880-2015
}

\section{Diego Castañeda Garza*}

February 2021

\begin{abstract}
This paper employs archival data to reconstruct the historical pattern of primary energy consumption in Mexico during the 1880-2015 period. The study highlights the characteristics of the energy transitions between different primary energy sources and offers the first account of both traditional and modern energy carriers. It performs a trend and level analysis to explain how the economic structure, population and economic growth have impacted energy intensity and productivity. Thus, the paper provides a first approximation to the long-term relationship between economic growth and energy utilisation in Mexico. The period 1880- 1920 saw both growths in population and income increase energy consumption, the period 1921-1960 is mostly driven by income growth, 1961-2000, both growths in population and income drive consumption, and finally, between 2001 and 2015, population growth is the dominant force.
\end{abstract}

Keywords: Energy, Energy Transitions, Mexico, Economic Growth, Energy Consumption JEL codes: N76, O13, P18, Q4

\footnotetext{
*Agenda for International Development, Department of Economics, ITESM-CSF: cgdiego@tec.mx
}

\section{Acknowledgements}

For the valuable comments and suggestions: Danae Hernández-Cortés and Jesús Carrillo. 


\section{Introduction}

Economic growth is one of the foundational topics in economic history (Bairoch 1985, Maddison 2007), accounts from the Industrial Revolution to the development paths of developed and developing countries emphasise growth. However, energy importance is often underplayed on several of those accounts. Energy impacts structural and technological changes, and as a growing literature suggests, the long-term relationship between economic growth gives us insight into the materialisation and "dematerialisation" of the economy thought time (Kander, Malanima and Warde 2013).

Traditional economic theories such as the Solow-Swan model (Solow 1956, 1974, Swan 1956) or the endogenous growth models (Romer 1986, Aghion 1992) focus on different sorts of capital accumulation but neglect the role of energy, thus avoiding thinking about it. In the traditional growth literature, capital accumulations play the central role as if capital could be accumulated without energy. These theories take energy as given and not as a constraint that influences the structure of the economy. On the other hand, proponents of ideas such as degrowth argue that economic growth goes hand in hand with increased energy utilisation as an inescapable fact and thus argue for less growth. Both accounts are mistaken. Growth needs energy, as all activities, productive or otherwise require it. Traditional growth theorists are optimistic for future energy transitions because they do not consider the constraining power of energy systems, and degrowers are too negative, denying that growth can occur without endlessly growing energy services. Both mistakes have the same root; they fail to recognise how energy shapes the economy and, therefore, how its structure and technology also influence the intensity in which we use our natural resources. For example, we can look at Allen (2009) account of the First Industrial Revolution.

The present paper tries to avoid those mistakes and looks to economic growth, technological and structural changes through the eyes of historical energy consumption. The study focuses on Mexico and its energy history; it is only the second Latin American country (After Uruguay, Bertoni 2011) to join a growing literature of energy historical national accounts that so far includes only a few countries (Canada, Germany, Netherlands, Sweden, Portugal, Spain, France, Czech and Slovak Republics, England, and Uruguay).

The study reconstructs traditional and modern primary energy carriers employing archival and statistical sources following the methods pioneered by Kander (2002), Malanima (2001, 2006), Warde (2007) and Henriques (2009, 2011). This historical national energy accounts reconstruction 
is divided for analysis into four periods: 1880-1920, 1921-1960, 1961-2000 and 2001-2015. It starts in 1880, just at the beginning of Mexico's electrification after its first electric plant was inaugurated in 1879. In a period of rapid capitalist development in which the economy began its industrialisation process. From 1880 to 1920 , we see the early industrialisation in a context of mostly traditional energy carriers. We saw the birth of the oil industry in 1901 and its first boom in the 1910s. The textile and mining industries were the first to employ electricity generated through hydropower and thermal energy (coal) to enhance their production and substitute fuelwood, water/windmills, and draft animals to perform their work.

From 1921 to 1960, we see the modern Mexican economy's development and how rapid per capita income and population growth increased energy consumption, exploiting modern energy sources' new availability. In this period, the expansion of the oil and electric industries takes place and power the country's rapid industrialisation; this is when the economy reaches its peak energy intensity levels and then a rapid decrease.

From 1961 to 2000, we observe a change. Population growth relegates income growth and takes the lead as the main factor behind energy consumption and slightly reverts the downward trend of energy intensity. This period is a crucial period of Mexican economic history as it contains the final years of the so-called "Mexican miracle" and its high rates of economic growth, the dreadful crisis years of the 1980s, and the beginning of the structural change from the peak industrialisation of the early 1980s to service economy in the 1990s.

Finally, the 2001-2015 period continues the dominance of population over income growth. However, in a very different context: an economy much more oriented towards services and more energy productive result of the Third Industrial Revolution's structural and technological changes. Therefore, this paper tells the economic history of Mexico as viewed from its energy transitions. In a period in which globally we debate the need for a new energy transition, the paper engages briefly in discussing what trends in the relationship between economic growth and energy consumption can be reasonably anticipated and how to reconcile them with our environment.

The paper is divided into the following sections: Data and methods, Structural Changes, Trend and level analysis, Energy consumption decompositions, Discussion and extensions, References, Appendix 1. 


\section{Data and methods}

Historical national energy accounts' reconstruction is an extremely time demanding activity, especially for developing countries that began collecting quality statistics around the last fifty years. The Mexican case is not different; it required the extensive revision of old statistical sources going back to the end of the 19th century, historical accounts of the period, reports, industry bulletins and secondary sources of the relevant period that had access to data. The reconstruction of the statistical series for energy consumption in Mexico closely follows the methodology pioneered by Kander (2002), Malanima (2006), Warde (2007) and Henriques (2009), but departs slightly when the available data did not allow us to follow it straightforwardly.

Some assumptions were made regarding the numbers for some traditional energy sources, such as windmills and watermills, draft animals, sailing ships, and fuelwood, for which data is scarce. Modern sources are less problematic as records exist from them, and the challenge is related more to the archival research to collect a vast number of statistics about the details of energy production, for example, the non-energy oil products such as lubricates and asphalts, and the different sources of electric power (hydroelectric, geothermal, thermoelectric).

\section{i. Traditional carriers}

Traditional carriers encompass the sources of energy available to men that have been used for centuries. The food we humans eat to perform work and survive, the fodder our draft animals eat to sustain their lives and perform the work we set for them. Fuelwood the likely older energy source for humanity, burn to heat us, cook and produce steam to move machines. Traditional sources also include two sources that are coming back, although in different ways: the wind that powered the sail ships for our trade, our wars, our fishing, that moved the vanes of windmills to grind our cereals and finally the water that with the help of the force of gravity energised old machines employing in grain production and textiles.

\section{Food:}

Food is perhaps the easiest to estimate, for the entire 1880-2015 period, we have good population statistics, we have estimates for 1880-1894 from the national historical statistics of Mexico and then from 1895 from the national censuses conducted by the Dirección General de Estadística and then by its successor institution Instituto Nacional de Estadística y Geografía (INEGI). We also have reconstructions of the standard of living among the population that goes back to colonial times, here we employ the bare bones basket of food estimated by Challú and 
Gómez-Galvarriato (2015) of 1,800 Kcal per day up to 1933, then we use their respectable basket of 1941 Kcal p.c per day up to 1960. From 1961 forward, we employ actual measurements of the Mexican population's caloric intake (Ortiz-Hernández, Delgado-Sánchez, and Hernández-Briones 2006) that steadily rises from 2407 Kcal p.c. per day in 1961 to 3139 Kcal p.c per day in the present.

\section{Fodder:}

For some countries that keep good statistics of cattle and draft animals, this calculation should be straightforward. It is the same logic as food, the caloric intake of the draft animal multiplied by its population. However, for the Mexican case, it is a little bit more complicated than that, agricultural censuses are scarce, particularly over the last 50 years; however, this is not a big problem because overall, the energy contribution of draft animals to the total energy consumption of a modern economy is small. However, for the pre-1930 period, some assumptions are required as statistics are not good. We have for some year's statistics of overall cattle for horses, donkeys, and cows; we start following Henriques (2009, p.56) and assume about the number of working horses and donkeys, we assume that $85 \%$ of the population worked. For cows, Henriques (2009) assumes that $66 \%$ of the population were working; we deviate the assumption since the Mexican economy in 1880-1910 was characterised by the hacienda economy and was exporting numerous heads of cattle to the U.S. For that reason, we believe it is a reasonable assumption that only $30 \%$ of those animals were draft animals. For the missing years, we relied on simple linear interpolations. It is important to mention that during the Mexican Revolution (1910-1920), the revolution was financed by cattle expropriation and increased exports to the United States; horses' death in battles diminished their numbers. Thus, we assume just $10 \%$ of animals were working in those years. We assumed 400 kilos of weight for horses and donkeys and a Kcal intake of 31,000 p.c per day. For cows, 24,000 Kcal p.c per day according to FAO manuals

\section{Fuelwood:}

As pointed by several authors in different fields from economic history, ecology, and forestry, accounting for the quantity of fuelwood consumed is full of uncertainties. Fuelwood has always been relatively easily accessible to rural populations, for most rural Mexico, at zero or near zero monetary cost. Overall estimation methods are either supply side or demand side. Supplyside counting methods rely on the yield by a hectare of wood of different species of trees, on welldocumented deforestation observations or a combination of both. The demand side relies on 
observations of actual consumption by rural populations in different climates and geographical areas. For the years between 1960 and 2015, we take the estimates of Díaz Jiménez (2000) and the statistics of the Secretaría de Energía (SENER). Before 1960 we consulted several sources, such as Masera (1993). However, the estimates for fuelwood p.c consumption did not reach far enough, we decided to use the estimates mentioned by Warde (2019) for Northern Spanish North America territories $3.1 \mathrm{~kg}$ p.c per day and subtracted $35 \%$ to account for the warmer climate of Mexico compared to the U.S. We arrived at an estimate of $2 \mathrm{~kg}$ p.c per day. To avoid overestimating fuelwood consumption, we did not multiply the number by the whole population. We employed the urbanisation rates reported in the national censuses to count the rural population. It is essential to recognise that further explorations can improve these estimates from the sources or by modelling consumption from populations' observations in similar climates, but we consider the current ones as good enough.

\begin{tabular}{|c|c|c|c|c|}
\hline Year & $\begin{array}{l}\text { Total } \\
\text { population }\end{array}$ & $\begin{array}{l}\% \text { urban population living in cities } \\
\text { exceeding } 5000\end{array}$ & $\begin{array}{l}\% \text { rural } \\
\text { population }\end{array}$ & $\begin{array}{l}\text { Rural } \\
\text { population }\end{array}$ \\
\hline 1895 & $12,632,000$ & 0.1054 & 0.8946 & $11,300,587$ \\
\hline 1900 & $13,607,000$ & 0.1054 & 0.8946 & $12,172,822$ \\
\hline 1910 & $15,160,000$ & 0.1176 & 0.8824 & $13,377,184$ \\
\hline 1921 & $14,335,000$ & 0.1454 & 0.8546 & $12,250,691$ \\
\hline 1930 & $16,553,000$ & 0.1747 & 0.8253 & $13,661,190$ \\
\hline 1940 & $19,654,000$ & 0.1998 & 0.8002 & $15,727,130$ \\
\hline 1950 & $25,791,000$ & 0.2791 & 0.7209 & $18,592,731$ \\
\hline 1960 & $34,923,000$ & 0.365 & 0.6351 & $22,179,597$ \\
\hline
\end{tabular}

Source: Population census 1895-1960, Dirección General de Estadística e INEGI.

\section{Wind and Water:}

Traditional wind and water energy are among the most complicated to estimate. It requires detailed records for windmills and watermills for grain, textile, and mining industries. It also depends on comprehensive statistics on merchant navies, number of ships, their class and tonnage.

For all these energy uses, sailing ships are the best-preserved statistics. The commerce and statistical yearbooks since 1892 include the reports of all commercial ships navigating Mexican waters and their class (vessels, sail ships, steams) and their tonnage up to the 1960s. Their number steadily declines from the 1880 s with about 2,000 ships and practically disappear by the $1940 \mathrm{~s}$ with just four ships. With these numbers, we apply Lindmark (2007) coefficient of $0.6 \mathrm{KW}$ per 
tonne and follow Henriques (2009, p.60) in assuming 3,650 yearly hours of use for commercial ships. There are no official records of fishing ships on the statistics, and therefore the estimate for sailing ships should be taken as a lower bound estimate.

For windmills and watermills, the situation is worse. There are scarce data. The early registry of mills is from 1857 in the document Las Memorias de Fomento del Siglo XIX. In this document, around 130 mills appear, without distinction of the type (wind or water) but based on the locations, is reasonable to assume watermills. Morales Moreno (2010, p.105) mentions that in the year 1828, in Puebla, there were 38 mills in Mexico City, 17 mills and Jalisco 45. Watermills for grain were disappearing at the end of the 19th century in Mexico City due to rising water conflicts and the new technologies.

To estimate the number of watermills, we start with the number registered in Las Memorias de Fomento del Siglo XIX and assume that it represents watermills for the textile industry. To calculate the possible number of watermills, we assume their number is growing at the same rate as the number of looms in the textile industry from 1879 to 1930 employing Gómez-Galvarriato data (2016, p.37-38). We assumed an average of 30 HP for industrial watermills (based on Puebla's textile industry). To convert these values to the energy, we assumed efficiency of $15 \%$ and 2,400 yearly hours of work using equation 1 :

$$
E=P * h * \frac{1}{i}
$$

Where:

$$
\begin{aligned}
& \mathrm{E}=\text { Energy consumption, } \\
& \mathrm{P}=\text { Power } \\
& \mathrm{h}=\text { Hours per year and } \\
& \mathrm{i}=\text { Efficiency. }
\end{aligned}
$$

Since no windmills nor watermills for grain could be identified on the records, we do not account for them. Further improvements can be made on traditional wind and water estimates.

\section{ii. Modern carriers}

Modern carriers include the energy sources of the industrial revolutions, coal, oil, natural gas, the so-called "primary electricity" or hydropower, geothermal energy, biogas, nuclear energy, solar and modern wind power. We are focusing on primary energy; therefore, fuels like gasoline or diesel produced are not counted as their energy was already inside the oil, and we would be 
double-counting, but it does include fuel imports converted to back to barrels of oil equivalent. It counts the imports of electricity and accounts for the energy losses due to the different efficiencies in the electricity plants. Modern energy carriers enable us to achieve modern economic growth with the First Industrial Revolution and the subsequent ones, therefore, are responsible for our modern world and the freedom to use labour and capital in more productive ways than just feeding us or performing manual work.

\section{Coal:}

The Historical Statistics of Mexico include mining statistics that go back to 1891. The statistical yearbooks and international trade yearbooks include data about coal exports and imports, and the national mining industry yearbooks provided by the Servicio Geológico Nacional (SGN) contained detailed statistics since the 1950s. A common problem in counting coal production is establishing the type of coal produced. Old statistics often ignore these details. Different types of coal have different efficiency coefficients according to their carbon content. For example, anthracite coal has a coefficient to convert it to tones of oil equivalent of 0.7 and lignite coal of 0.27. Luckily, the American Society for Testing and Materials (ASTM) estimates that coal reserves around the world are divided into the following shares according to their type:

\section{Figure 1: Mexican coal reserves}

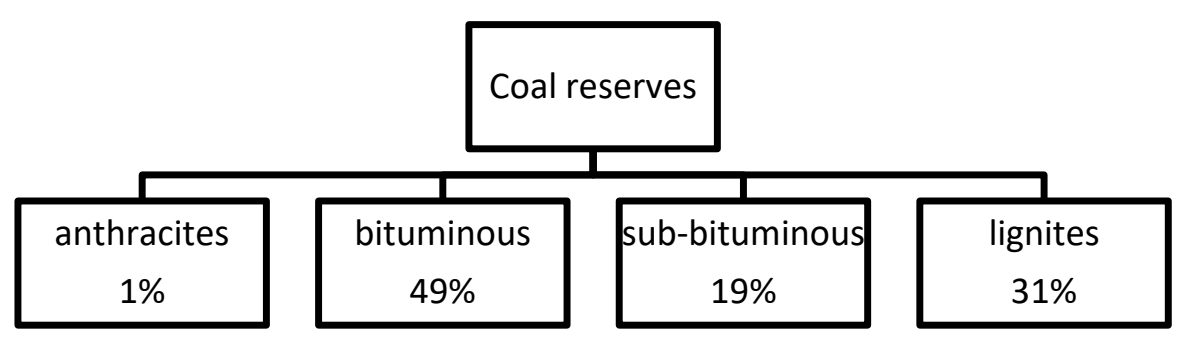

Source: ASTM.

We divide total production by each category and convert to tonnes of oil equivalent using the conversion coefficients, then we add the imports and subtract the exports according to their classification in the yearbooks. 
Oil:

Oil production in Mexico started in 1901 with roughly 10 thousand barrels but rapidly grew since then. By 1913 Mexico exported close to $70 \%$ of its 25 million barrels production, $90 \%$ around the first global oil shortage 1918-1922 (Rubio 2006). In those years, Mexico represented around a quarter of world production with its 185 million barrels. During the decades of 1920-1930, production expanded and started to dominate the country's primary energy production. In 1938, the oil industry nationalisation year, oil represented $43 \%$ of the total primary energy consumption. After nationalisation, the country's imports of the oil industry increased, becoming a crucial revenue source. As a share of primary energy consumption, it reached its peak in 1994 with 63\%. Oil accounting is a straightforward procedure. Historical statistics, yearbooks, Pemex reports and the British Petroleum historical statistics account for the same production from 1901 onwards. Since we are looking only at primary energy production, we do not count production fuels, such as gasoline. We deduct oil derivatives such as lubricates or asphalts as their production is not for energy purposes. We count the fuel imports and convert them to barrels of oil equivalent using the BP Statistics conversion rates.

\section{Natural Gas:}

Natural gas is also easy to count. Historical statistics and yearbooks register the first imports of natural gas at the end of the 1940s, and production increases since that time. Natural gas production in Mexico is not as important as oil, but since the late 1960s, it has increased its share of total primary energy consumption from around $5 \%$ to around $20 \%$ in recent years. We add the production statistics and the import statistics and subtract the exports.

\section{Primary Electricity:}

Electricity is a secondary form of energy, but the economic history literature has always grouped non-fossil generated electricity under the label "Primary electricity" to facilitate economic analysis. We follow that tradition and group as "Primary electricity" the electricity generated by hydropower, geothermal power, wind power, solar power, and nuclear power.

Statistics from hydropower go back to the first electrification of the country in the 1880 s when $38.8 \%$ of electricity was hydropower (Garza Toledo et al. 1994, p. 19). From 1880 to 1932, we base our estimates on Garza Toledo et al. (1994) and from 1932, we rely on the statistical yearbooks and SENER. The official statistics do not account for the losses. To account for losses and produce a better estimate, we assume following Henriques (2009, p.90), 25\% losses between 
1880 and 1960, $15 \%$ between 1961 and 1990, and 8\% losses from 1991 to 2015 (the percentage of loses reported by SENER), those percentages reflect the technological change in hydropower plants. Finally, we add imports and subtract exports.

Nuclear, geothermal, solar, and wind energies started to be developed in Mexico from the mid1980s. SENER statistics exist since the 1980s and 1990s; thus, it is not difficult to count them. We follow the same procedure as before but with different efficiency levels to account for energy losses. We assume a $15 \%$ efficiency for solar power, for wind power a $40 \%$ efficiency, for geothermal a $12 \%$ efficiency and finally, for nuclear energy, we assume $37 \%$ efficiency.

\section{Biogas:}

Biogas statistics by SENER exist since 1999. We do not perform any adjustment.

\section{Structural changes}

After all the estimates presented above, it is possible to discern the country's energy transitions. Even if some estimate might need revision and improvements, the overall picture can hardly be contested; it would require massive energy consumption differences to alter the transitions' shape.

Figure 2: Transition from traditional to modern energy

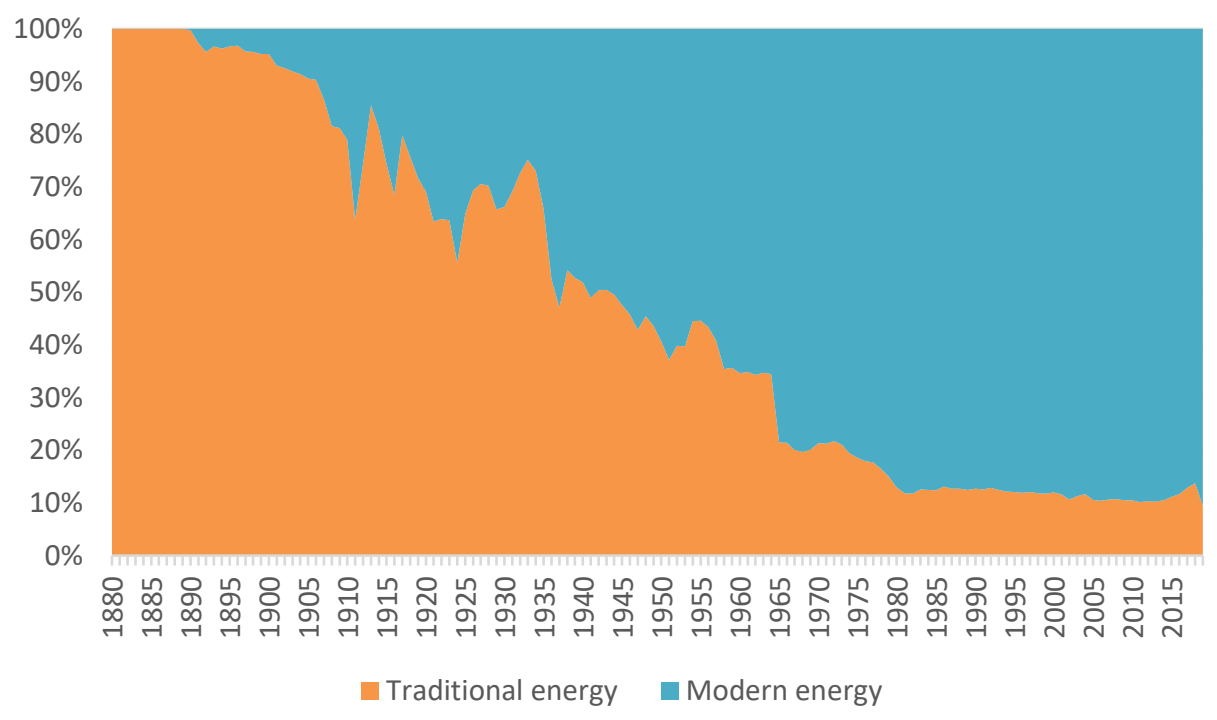


Figure 3: Per capita energy consumption (PJ) 1880-2015

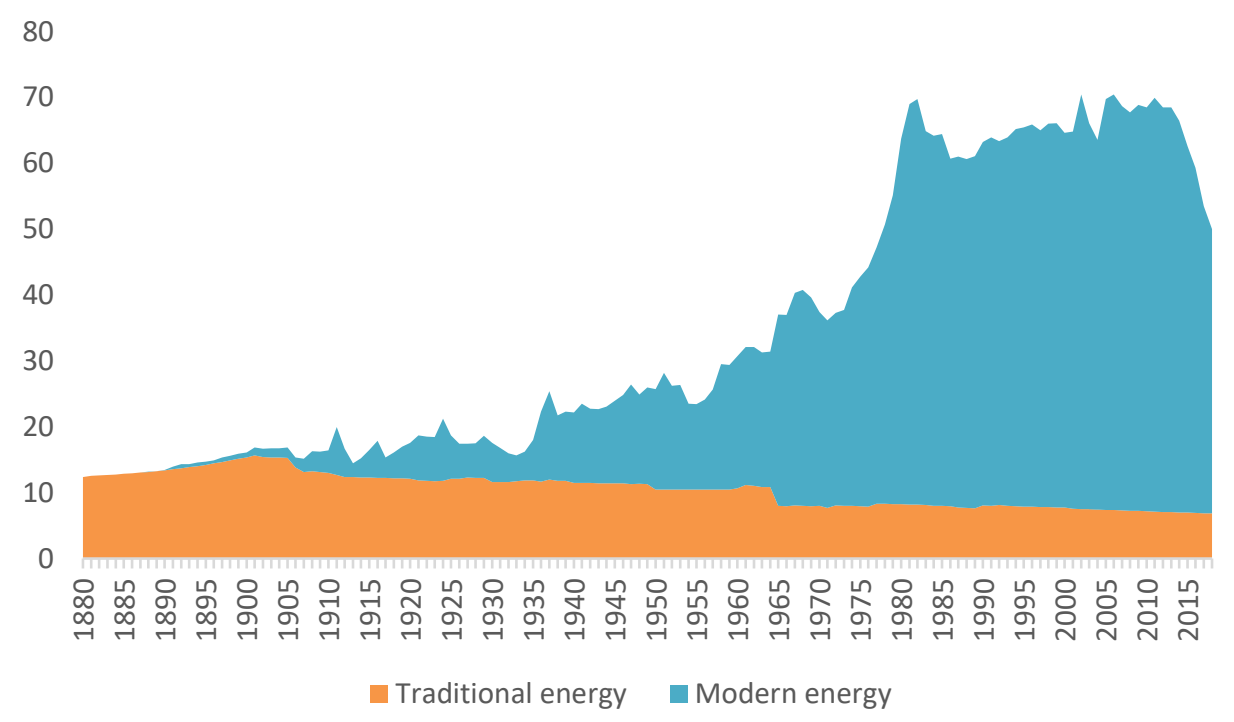

Figures 2 and 3 above show how, in terms of energy consumption sources, Mexico skipped the first and second industrial revolutions. Modern energy sources did not overtake traditional ones up until 1944. However, structural change starts to show at the end years of the 19th century. A closer look at the transition, observing all carriers, demonstrates that energy transitions have been a continued and long-term process for Mexico.

\section{Figure 4: Mexico's energy transitions}

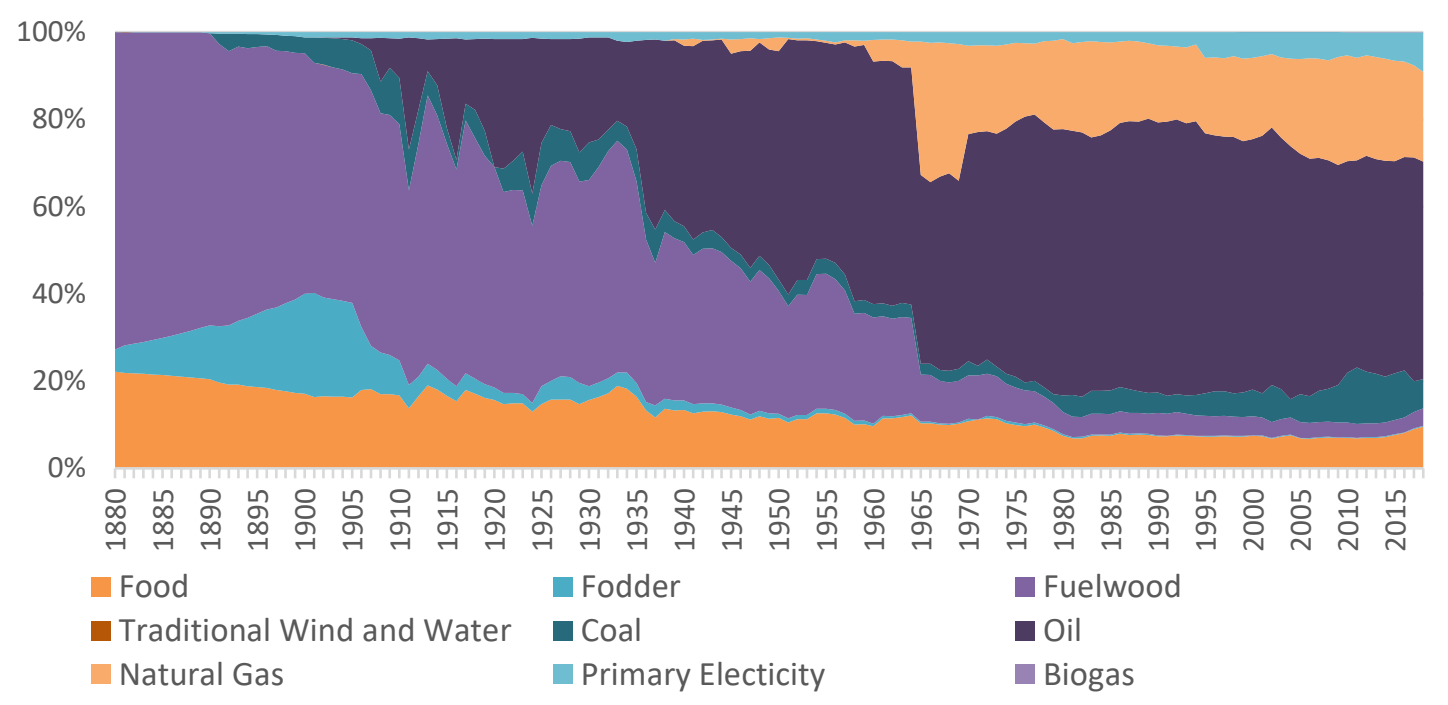


In 1880 energy consumption was entirely dominated by food, fodder and fuelwood. Mexico was a rural country with small industries and huge communication barriers due to lack of infrastructure and geographical constraints (lack of navigable rivers and rough terrain). Mexico starts to be more connected in the 1890s with the construction of railroads between the north and the centre of the country, and with them came increased urbanisation. New towns and growing cities provided for the inner demand that stimulated some industrial progress. For example, we see the expansion of brewery, mining, and textiles. Is not a coincidence that coal enters the energy matrix around this time. In 1891 coal represented just $2.4 \%$ of total primary energy consumption, and by 1910 the year of the Mexican Revolution, it peaked at almost 11\%, a level it will not reach again until 2010.

Coal never was for Mexico what it was for England and other European countries with comparable data. Mexico leapfrogged coal development and instead rapidly developed its oil industry. As mentioned before, the exploitation of oil started in 1901 and by 1914-1922, driven by the Great War, Mexico became the second world producer (Rubio 2006). Oil provided the energy resources to start the new rounds of industrialisation. Although electricity started in 1879 by the 1920s, it was stile mostly used for lighting purposes. According to Garza Toledo (1994), only $10 \%$ of electricity was used for industrial activities. In the 1930s, with the creation of the state energy enterprises, Pemex and CFE, Mexico embraced the Second Industrial Revolution's catching-up process and, as Haber (1989) argues, Mexico started to utilise its idle industrial capacity. Modern energy liberated Mexico's industrial prowess.

By the 1940s, oil was the dominant energy carrier. It accounted for almost $50 \%$ of all energy consumption. By the 1950s and 1960s, it was nearing 60\%. This acceleration is not a surprise. Mexico experienced its fastest industrial growth, accelerating both the transition from a rural economy dominated by agriculture and traditional energy such as draft animals and fuelwood towards dominion by industry and modern energy. These are the years that see Mexico complete its transition from agrarian to industrial. In the 1960s and 1970s, we see natural gas enter the equation at full force. Factories increasingly imported natural gas, and national production also rose. By the late 1970s and the beginning of the 1980s, fossil fuels (oil, natural gas, and coal) represented more than $86 \%$ of all primary energy consumption. 
Table 2: Composition of primary energy consumption in Mexico (1880-2015)

\begin{tabular}{lrrrrrr}
\hline \hline Source & 1880 & 1910 & 1940 & 1970 & 2000 & 2015 \\
\hline Food & $22.20 \%$ & $17.28 \%$ & $13.36 \%$ & $10.78 \%$ & $7.40 \%$ & $7.61 \%$ \\
\hline Fodder & $4.99 \%$ & $8.21 \%$ & $2.20 \%$ & $0.58 \%$ & $0.17 \%$ & $0.14 \%$ \\
\hline Fuelwood & $72.80 \%$ & $55.87 \%$ & $36.31 \%$ & $9.94 \%$ & $4.40 \%$ & $3.31 \%$ \\
\hline Traditional Wind and Water & $0.001 \%$ & $0.00003 \%$ & $0.000001 \%$ & $0 \%$ & $0 \%$ & $0 \%$ \\
\hline Coal & $0 \%$ & $10.92 \%$ & $3.60 \%$ & $3.22 \%$ & $6.08 \%$ & $10.60 \%$ \\
\hline Oil & $0 \%$ & $9.32 \%$ & $41.36 \%$ & $52.09 \%$ & $57.36 \%$ & $48.33 \%$ \\
\hline Natural Gas & $0 \%$ & $0 \%$ & $1.48 \%$ & $20.17 \%$ & $18.58 \%$ & $22.83 \%$ \\
\hline Primary Electricity & $0.01 \%$ & $1.52 \%$ & $1.69 \%$ & $3.14 \%$ & $5.88 \%$ & $6.51 \%$ \\
\hline Biogas & $0 \%$ & $0 \%$ & $0 \%$ & $0.00 \%$ & $0.0002 \%$ & $0.02 \%$ \\
\hline
\end{tabular}

Table 3: Mexico and European countries 1950

\begin{tabular}{lrrrccc}
\hline \hline Source & Mexico & Italy & Spain & Portugal & Sweden & $\begin{array}{l}\text { England \& } \\
\text { Wales }\end{array}$ \\
\hline Food + Fodder & $13 \%$ & $27 \%$ & $27 \%$ & $24 \%$ & $6.00 \%$ & $3 \%$ \\
\hline Fuelwood & $28 \%$ & $17 \%$ & $12 \%$ & $44 \%$ & $21.00 \%$ & $0 \%$ \\
\hline Traditional Wind and Water & $0 \%$ & $0 \%$ & $0 \%$ & $1 \%$ & $<1$ & $0 \%$ \\
\hline Fossils (oil+natural gas + coal) & $58 \%$ & $47 \%$ & $59 \%$ & $30 \%$ & $64 \%$ & $97 \%$ \\
\hline Primary Electicity & $1 \%$ & $10 \%$ & $2 \%$ & $1 \%$ & $9 \%$ & $0 \%$ \\
\hline
\end{tabular}

Source: Mexico: Author's estimates. Italy (Malanima 2006), Portugal (Henriques 2009), Sweden (Kander 2002), England and Wales (Warde 2007), Spain (Kander, Gales, Rubio and Malanima 2007). Note* numbers are rounded at the nearest integer.

In Tables 2 and 3, we can see the full extent of Mexico leapfrogging transition between energy carriers. In 1880 the country was a pre-industrial economy. By 1940 it was starting to catch up to a level comparable to the Europeans in terms of oil. By 1950, it was at comparable levels of fossil fuels consumption as a share of their respective energy matrixes with Spain and Sweden, had a higher level than Italy and was well above Portugal. Although a late starter, Mexico catches up with the European countries in terms of the oil transition.

By the 1980s, the debt crisis hit the country at its peak in industrial employment and started a new structural change process. Informality rose as the public sector dwindle, and large nationalised businesses were privatised and rationalised. The country began a process of slow deindustrialisation and started to move towards the service sector. In 1984, for the first time, oil accounted for nearly $60 \%$ of the primary energy consumption and steadily rose to $62 \%$ in 1994 . At the period we see the so-called primary electricity start its climb and reaches $3 \%$. The first 
nuclear plant in 1991, the beginning of the wind, solar and geothermal energy sources from the mid-1980s to the end of the 1990 s, takes primary electricity to $6 \%$ of total consumption.

At the beginning of the XXI century, we see primary electricity stagnate and fluctuate around $6 \%$ until 2015. The new century brought instead what might be considered the age of natural gas, "the fuel of the 21st century," as Vaclav Smil (2015) calls it. Since the turn of the century, the country has shifted towards the service economy while maintaining a declining but still strong industrial base in high tech sectors such as the automotive, aerospace and metal mechanic. The 21 st century sees a double transition, a transition from industry to services and oil to gas, and a little bit of a resurgence for coal. This double transition has feedback effects on structural change and energy.

The Third Industrial Revolution has made the industry more efficient with intelligent systems and automation. Cheaper energy sources such as natural gas have increased electric availability and reliability with combined cycle power plants and, as we will see in section IV, without increasing energy intensity.

Figure 5: GDP (1990GK) and total energy consumption (MJ), 1880-2015

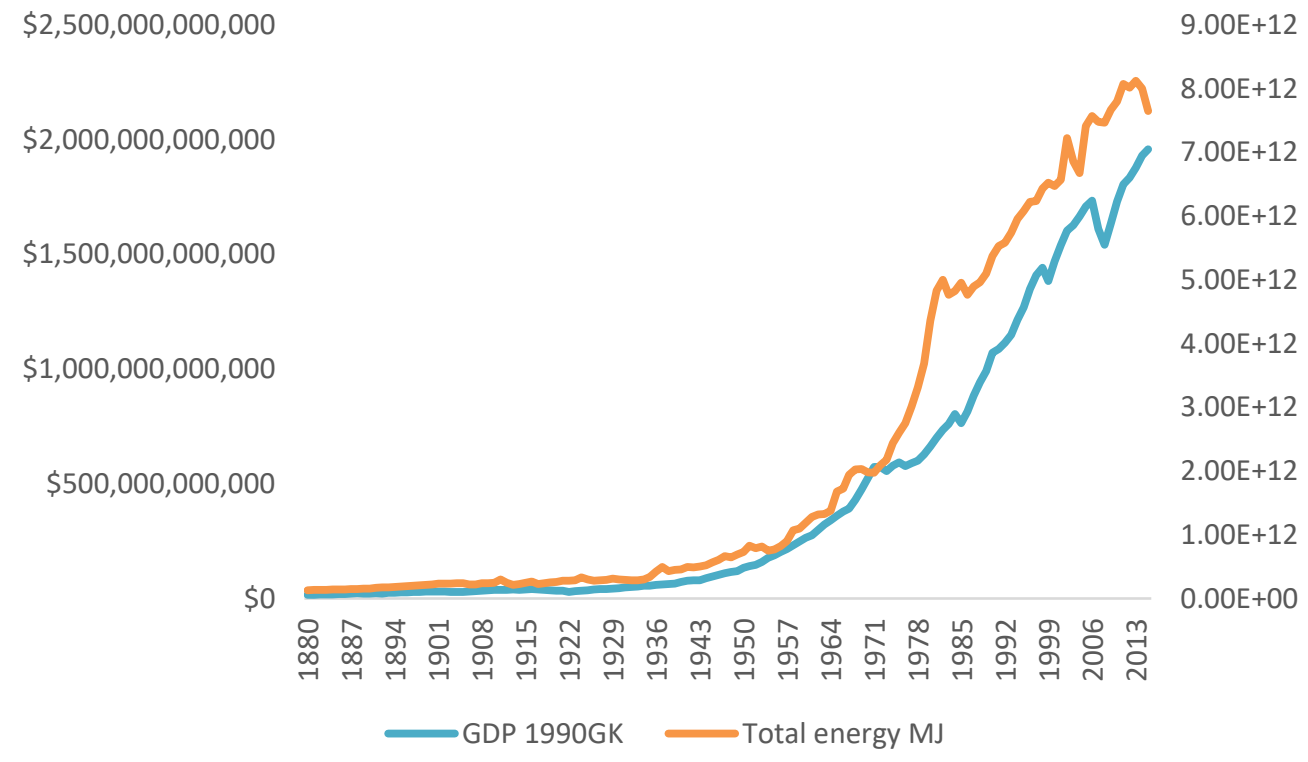

To what extent this 135-year history of consumption is the result of structural changes in the economy? Is economic growth responsible for rising energy consumption? Figure 5 appear to suggest that, yes, income growth is positively correlated with energy consumption. However, could that correlation be the whole story? 
Of course not, and there is an easy way to check it. How economic growth and the structural changes that allow it to have impacted energy consumption? A way to find the answer is to perform the famous Commoner-Ehrlich decomposition (Ehrlich and Holden 1971, Commoner 1972), a simple breakdown of energy consumption into its components. Equation 2 presents the decomposition:

$$
E=P * \frac{Y}{P} * \frac{E}{Y}
$$

$$
\begin{aligned}
& \text { Where: } \\
& \mathrm{E}=\text { Energy consumption, } \\
& \mathrm{P}=\text { Population, } \\
& \mathrm{Y}=\text { GDP. }
\end{aligned}
$$

Equation 2 can also be expressed as growth rates:

$$
e=p+y+e_{y}
$$

Where:

$\mathrm{e}=$ the growth rate of energy consumption,

$\mathrm{p}=$ the growth rate of population,

$\mathrm{y}=$ GDP per capita growth,

$e_{y}=$ energy intensity ${ }^{1}$ growth rate.

Although this type of decomposition does not tell us the precise cause of the changes in energy consumption, it gives us a first approximation of what is behind energy consumption. We are dividing our 135 years into four periods that roughly match the historical developments. We observe that per capita income growth is not always behind rising energy consumption. Table 4 breaks it down.

\footnotetext{
${ }^{1} \mathrm{E} / \mathrm{Y}$ in equation 2 refers to energy intensity. Energy consumption in energy units divided by GDP. An economy with high energy intensity means it requires more energy per dollar, an economy with low energy intensity gets more dollars per energy unit, which means it has higher energy productivity.
} 
Table 4: Commoner -Ehrlich decomposition for Mexico

\begin{tabular}{ccccc}
\hline \hline Period & $\mathrm{e}$ (average) & $\mathrm{p}$ (average) & $\mathrm{y}$ (average) & ey (average) \\
\hline $1880-1920$ & 0.01940496 & 0.00882982 & 0.00977851 & -0.00255194 \\
\hline $1921-1960$ & 0.04132881 & 0.0241269 & 0.0293697 & -0.02465936 \\
\hline $1961-2000$ & 0.04466644 & 0.02409613 & 0.01977966 & 0.00158377 \\
\hline $2001-2015$ & 0.01211421 & 0.01303616 & 0.00677701 & -0.00718666 \\
\hline
\end{tabular}

From 1880 to 1920 , income growth dominates, followed by population growth. Energy intensity decreases, and this slightly mitigates energy consumption. The negative rate of change in energy intensity reflects the beginning of a shift between traditional and modern energy sources. In the 1921-1960 period, we see that economic growth dominate population growth; in fact, the negative rate of intensity change more than compensates for population increases. This period sees Mexico catch up to the European countries, see Table 3, and when Mexico finally transited to modern energy carriers and from a pre-industrial economy to an industrial one. This evidence strongly suggests structural change. From 1961 to 2000, we observe rapid population growth (2.4\% per year), at that rate population doubles roughly every 29 years. Population growth dominates income growth, and energy intensity increases, temporally reverting the diminish trend in energy intensity. The enormous discoveries of oil ensured cheaper energy and thus, disincentivised energy savings. Mexico reached its highest industrialisation level in the 1980s and endured the hardest economic crisis in his modern history. Finally, the 2000-2015 period is again dominated by population growth, not income. Energy intensity return to its diminishing trend. In figure 5, we can corroborate this as the gap between energy consumption and GDP increases for most of the 1960-2015 period.

The fact that population rather than economic growth is behind the changes over the last 50 years can have different explanations. It tells us something about the relative stagnation in living standards that the country has endured since the 1980s, in which per capita income growth has been barely around $1 \%$. Nevertheless, it also suggests that there are technological and structural reasons behind diminishing energy intensity. 


\section{Trend analysis}

To further explore the relationship between economic growth and energy, we can analyse economic output and energy consumption. That is looking at energy intensity and energy productivity (efficiency).

$$
\begin{aligned}
& \text { Energy Intensity }=E_{y}=\frac{E}{Y}, \\
& \text { and its inverse, energy productivity }=P=\frac{Y}{E}
\end{aligned}
$$

Figure 6: Energy intensity and energy productivity, 1880-2015

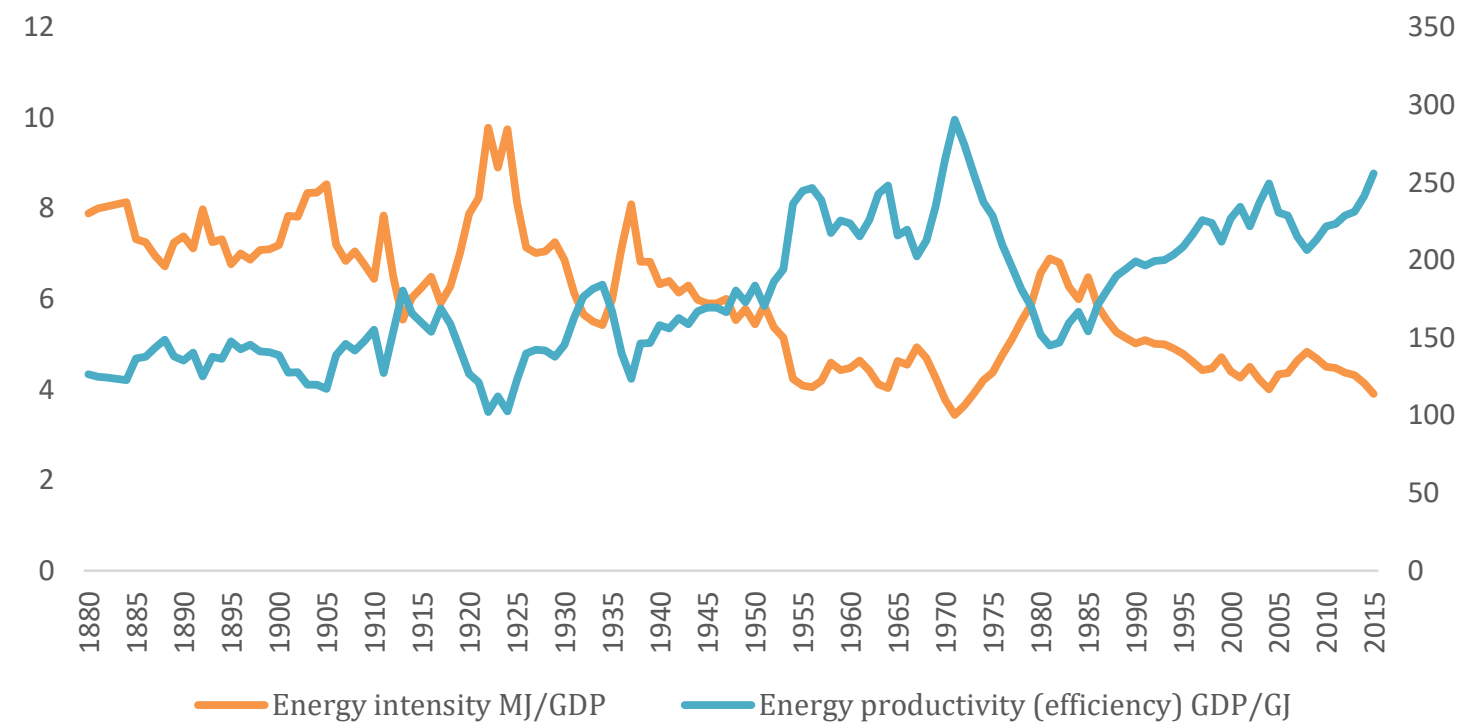

Note* MJ in the left axis, 1990GK dollars per GJ in the right axis. Energy productivity is expressed in dollars/GJ to facilitate interpretation.

As we can see in Figure 6, the trend of energy intensity is downwards. It does not exhibit the inverted U pattern of an environmental Kuznets curve (Penayotou 1993) that is possible to observe in England (Warde 2007). That rapid decline in intensity is most likely the result of a combination of factors, the higher GDP achieved through industrialisation and enabled by the change in energy carriers. There are only two breaks in that pattern. In the 1910s, the Mexican Revolution produced a fast decline in the economy, and at the same time, the massive increase in oil production for exports in the context of the Great War. During the 1920s, the slow recovery from the revolution and the Great Depression at the end of that decade. Energy productivity hits its lowest point during this period. The second is during the 1970s and 1980s. Mexico's colossal oil discoveries came in 1971, and public investment raised increasing GDP, which is reflected in 
the peak in energy productivity. The oil crisis of 1973 and the subsequent economic difficulties, combined with a massive increase in oil production from 1978 onwards, productivity collapses and intensity rises, temporarily reverting its long-run declining trend. The 1980s, with the economic decline, deindustrialisation, and rising energy production, ensured a rising energy intensity. After the 1980s, the 1990s see a return to the long-term trend. Not even the crisis of 1995 and 2009 had the reversal effects of the revolutionary period of the 1980s.

This reversal of the trend in itself provides evidence of how severe the 1980s was for Mexico, in energy terms and not counting exceptional times such as the revolution. It is the harder crisis in modern Mexican history.

Looking at the economic output as a function of energy confirms this narrative. Figure 7 displays the energy consumption and GDP per capita; it draws a fourth-degree polynomial ${ }^{2}$ as the best fit and shows a clear inverse $\mathrm{S}$ shape.

\section{Figure 7: Per c. GDP and Energy Consumption 1880-2015 (1990GK and GJ)}

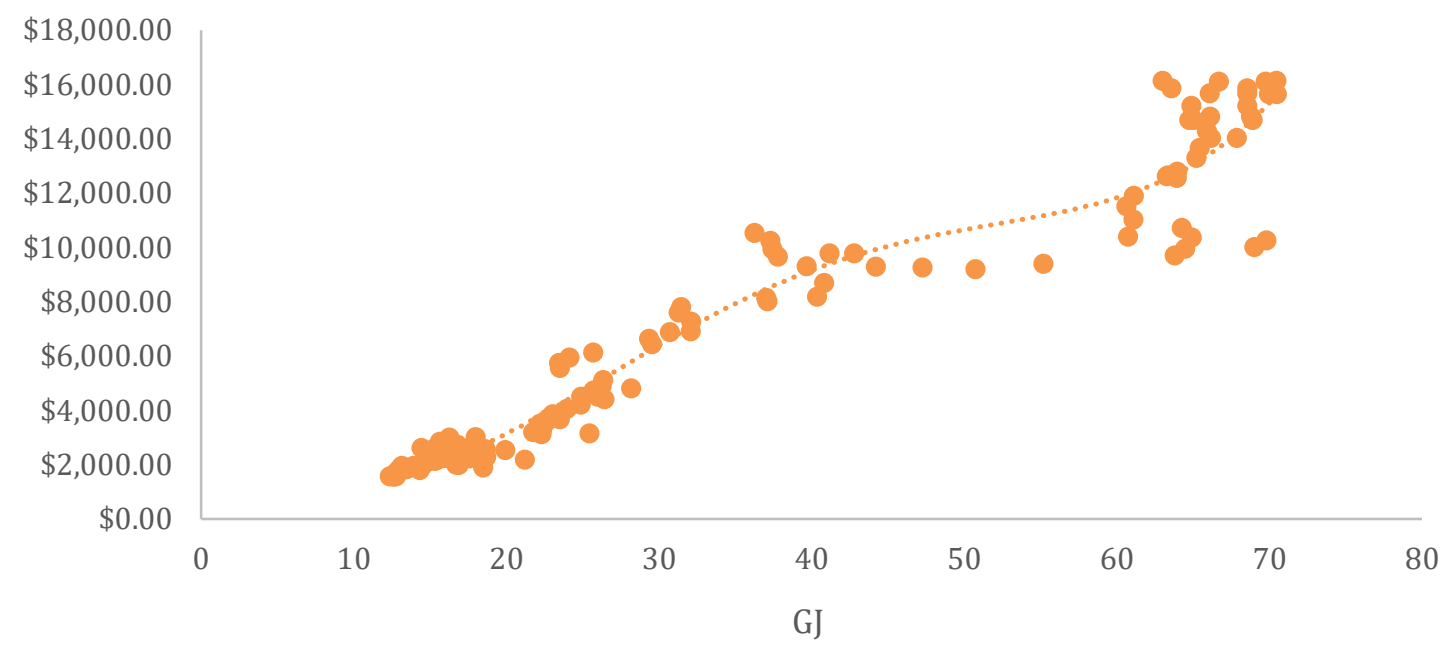

The $S$ shape of the curve can be interpreted in the following way, at the beginning of the transition from agrarian to industrial, substituting draft animals and firewood for machines and mineral sources of energy increases the energy productivity. The rising slope of the curve points towards a high elasticity between GDP per capita and energy consumption. After Mexico catches up to European levels (see Table 3), the slope decreases, signalling lower elasticities and a propensity to save less energy, this combines with the crisis and the stagnation of the economy. After the 1990s, when the economy started transitioning towards services and shifting towards

${ }^{2} e=\alpha+\beta_{1} y+B_{2} y^{2}+B_{3} y^{3}+B_{4} y^{4}+\varepsilon$ 
natural gas, the slope became steeper again, pointing to higher elasticity. In this later period, energy productivity returns to its rising trend.

\section{i. Logarithmic mean divisia index decomposition, 2005-2017.}

One critical aspect of the relationship between economic growth and energy consumption is if decoupling is possible. General trends suggest that the structure of the economy and technological changes make this possible; however, it is hard to test in a historical setting due to the lack of full sectoral energy accounts. Nevertheless, at least it is possible to test for as long as sectoral energy statistics exist. For the period 2005-2017, SENER publishes full detailed sector energy statistics. We can test if the service transition and its technological underpinnings provide evidence for the economy's dematerialisation. We use the logarithmic mean divisia index decomposition method (Ang 2005, 2015).

Following Ang (2015), we perform a multiplicative decomposition of activity, structure, and energy consumption intensity. The Model is expressed in the following equations:

$$
\begin{aligned}
& \mathrm{D}_{\text {str }}=\exp \left[\sum_{\mathrm{i}} \mathrm{w}_{\mathrm{i}}^{\prime} \ln \left(\frac{\mathrm{s}_{\mathrm{i}}^{\mathrm{T}}}{\mathrm{S}_{\mathrm{i}}^{0}}\right)\right] \\
& \mathrm{D}_{\text {int }}=\exp \left[\sum_{\mathrm{i}} \mathrm{w}_{\mathrm{i}}^{\prime} \ln \left(\frac{\mathrm{I}_{\mathrm{i}}^{\mathrm{T}}}{\mathrm{I}_{\mathrm{i}}^{0}}\right)\right] \\
& \mathrm{D}_{\text {pcons }}=\exp \left[\sum_{\mathrm{k}} \mathrm{w}_{\mathrm{k}}^{\prime} \ln \left(\frac{\frac{\mathrm{E}_{\mathrm{k}}^{\mathrm{T}}}{\mathrm{Y}^{\mathrm{T}}}}{\frac{\mathrm{E}_{\mathrm{k}}^{0}}{\mathrm{Y}^{0}}}\right)\right]
\end{aligned}
$$

Where:

Dstr $=$ structural decomposition,

Dint $=$ intensity decomposition,

Dpcons $=$ consumption decomposition,

$\mathrm{w}^{\prime}=$ sectorial weights of energy intensity,

$\mathrm{St}=$ value added share of a sector,

It = energy intensity of a sector,

Et $=$ energy intensity of the residential sector. 
Historical Energy Consumption, Transitions and Economic Growth 1880-2015.

Table 5: LMDI decomposition results, Mexico 2005-2017

\begin{tabular}{|c|c|}
\hline Sector & $\%$ change (constant pesos 2013) \\
\hline \multicolumn{2}{|l|}{ Agriculture } \\
\hline Structure & 1.001842888 \\
\hline Intensity & 0.988341603 \\
\hline \multicolumn{2}{|l|}{ Industry } \\
\hline Structure & 0.939492389 \\
\hline Intensity & 1.000123059 \\
\hline \multicolumn{2}{|l|}{ Services } \\
\hline Structure & 1.003457274 \\
\hline Intensity & 0.970569696 \\
\hline \multicolumn{2}{|l|}{ Transport } \\
\hline Structure & 1.030238196 \\
\hline Intensity & 0.765846465 \\
\hline Residential & 1.122830953 \\
\hline \multicolumn{2}{|l|}{$\begin{array}{l}\text { Total productive } \\
\text { sector }\end{array}$} \\
\hline Structure & 0.973037143 \\
\hline Intensity & 0.734732003 \\
\hline Total household & 1.122830953 \\
\hline Total & 0.802736022 \\
\hline
\end{tabular}

Note* The results are presented in constant prices to account for Baumol's disease, see Kander (2005). 
Figure 8: LMDI decomposition, México 2005-2017.

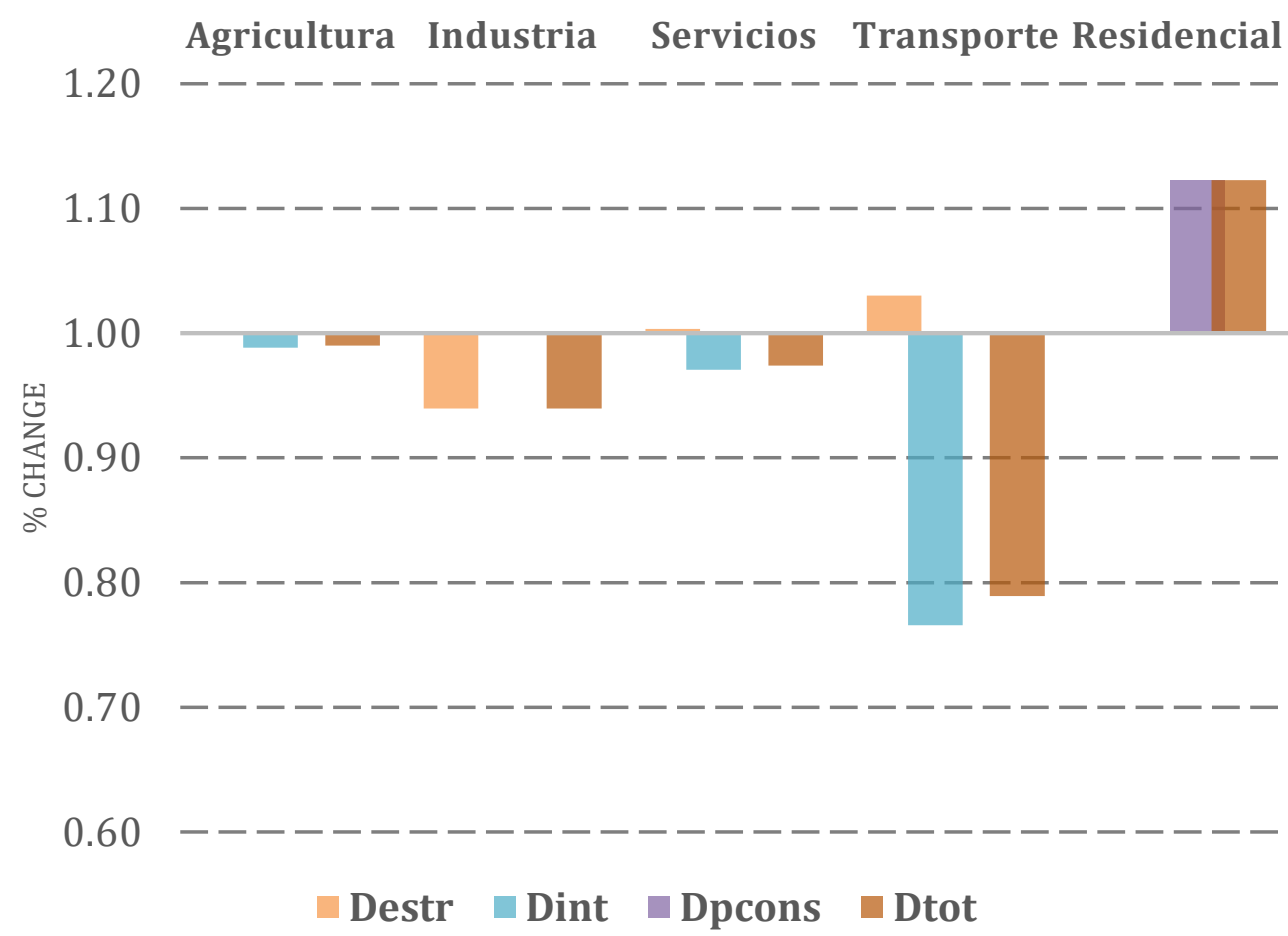

The LMDI decomposition results for the period 2005-2017 are presented in Table 5 and Figure 8. How to interpret the results? $?^{3}$ The agricultural sectors show a marginal structural increase in the export of agricultural products such as avocados, blueberries and blackberries has enjoyed a boom. Simultaneously, its intensity has shown a small reduction of $1.2 \%$, signalling technological improvements in agriculture. The industrial sector shows clear signs of structural change as it decreases $6.1 \%$ but marginally increases its intensity $0.0001 \%$; since Mexico has increased its manufacturing exports and venture into some advanced manufacturing, we could interpret this result as better technology offsetting the production increases. The service sector also shows a marginal structural increase and a 3\% decrease in intensity; a growing sector that reduces intensity is likely the result of the information and communication revolution. Transportation exhibits significant structural change, a 3\% increase; this phenomenon can have different explanations; increasing trade volume, rising urbanisation and the growing numbers of cars per

\footnotetext{
${ }^{3}$ A different version of this analysis of the LMDI decomposition was first presented in Castañeda, D. (2019). Consumo de energía y el crecimiento económico de México. https://economia.nexos.com.mx/?p=2198
} 
capita. However, intensity shows a significant reduction of $23.5 \%$; this results from technological change, more efficient motors, and better fuels.

Overall, the LMDI decomposition showcases a $19.8 \%$ reduction in energy intensity, a modest sign of dematerialisation of the economy. Most of it driven by technological change, with structural change having a minor role. The Third Industrial Revolution with the information technologies has accelerated the transition to services creating new services, making more efficient previously existing ones, and making manufacture more efficient. We cannot disentangle the technological revolutions from the structural changes in the economy and energy consumption. Much like the First Industrial Revolution show us that industry, cheap energy, and innovations went hand in hand (Allen 2009); what we observe in the 21st-century displays similar relationships.

The decomposition performed in this subsection offers the same interpretation of the energy intensity and productivity trends. It supports the argument that energy relationship with the economy is complicated, causality flows in both directions, energy creates opportunities for economic growth and economic growth, and its nature (structure, technology) changes how we use energy. If we could construct complete sectoral statistics for energy consumption for the whole 1880-2015 period, in theory, we could observe how these changes in structure and technology drive the long-term trends we analyse in this section. Develop historical sectorial statistics remains an extension to be made to this work.

\section{Discussion and extension}

This paper contributes to the historical national research accounts literature by developing the first iteration of primary energy consumption trends for 135 years in Mexico. It adds an essential example of literature that mostly concentrate on developed economies. It also analyses structural and trend changes that display the complexity of the relationship between economic growth and energy consumption. It finds evidence that suggests a possible interpretation of Mexican economic history as seen through the eyes of energy.

Mexico energy transitions fit well to the development stages of the economy on those 135 years. It reflects its backwardness in pre-industrial times. Its accelerated catching-up process in the middle of the 20th century. The catastrophic 1980s and its recent double transition from industry to services and from oil to natural gas. 
The finding that population growth has dominated economic growth over the last 50 years as the primary source behind energy consumption highlights, on the one hand, the positive side that the economy can grow without putting more pressure on resources. However, on the other hand, the negative side that attests to how long the Mexican economy has stagnated. The LMDI decomposition performed for the 2005-2017 period suggests how the dynamic forces of structural and technological change can shape the economy's materialisation or dematerialisation.

Thinking about our current debates and need for a new energy transition, México is an example for the developing world, is an example that is possible to leapfrog between energy sources. Our historical energy consumption reconstruction demonstrates the leapfrogging from traditional energy sources to oil, almost entirely bypassing coal. However, modern energy systems are so intertwined with their infrastructure and their technical systems (transmission networks) that any transition requires enormous capital investment as it requires to renew infrastructure. The choosing of energy carries produces path dependency, is not easy to switch between energy sources. This fact leaves us with the crude reality that unless the capital energy relationship increases, it will be unrealistic to expect a fast transition. Without more capital, any transition will be gradual. In that sense, a diversified energy matrix that combines more primary electricity sources with natural gas and oil appear to be the feasible path for the near future.

As Kander, Malanima and Warde (2013) suggest, industrial revolutions and energy transitions are linked. Changes in technical systems compound changes in technology that themselves produce changes in demands of energy. Technical systems are often where critical innovation occurs. Just attempting to change energy carriers without thinking on the infrastructure side and without entirely reframing the production methods and consumption patterns will be an obstacle to any idea of a fast transition. Large investments around general-purpose technologies and economies of scale are necessary to the appearance of developing blocks (Dahmén 1950, Enflo, Kander and Schön 2008). In this understanding, nothing short of an industrial revolution will produce the next transition. Maybe one of those revolutions is on the horizon, as Niels Bohr said and later was popularised by the Yankees catcher Yogi Berra: "Prediction is very difficult, especially if it's about the future!" 


\section{References}

\section{i. Archival and statistical sources}

British Petroleum. Statistical Review of World Energy. 1951-2019.

Consejo de Recursos Mineros de México. Anuarios Estadístico de la Minería Mexicana (19692019). Servicio Geológico Nacional.

Departamento de los Censos. (1959). Censos Agropecuarios 1930,1940 y 1950. Talleres Gráficos de la Nación, D.F: México.

Dirección General de Estadística. (1956). Estadísticas Sociales del Porfiriato 1877-1910. Talleres Gráficos de la Nación, D.F: México.

Dirección General de Estadística. (1894-1907). Anuarios Estadísticos de la República Mexicana 1893-1907. Oficina de la Secretaría de Fomento.

Dirección General de Estadística. (1939-1970). Anuarios Estadísticos de los Estados Unidos Mexicanos 1938-1970. Departamento Autónomo de Prensa y Publicidad, D.F: México.

Dirección General de Estadística. Censos Generales de la República Mexicana 1895/1900/1910/1921/1930/1940/1950/1960/1970. D.F: México.

Dirección General de Estadística. (1930). Primer Censo Agrícola Ganadero 1930. Talleres Gráficos de la Nación, D.F: México.

Dirección General de Estadística. (1937-1949). Censos Ejidales 1935-1949: Resumen General. Departamento Autónomo de Prensa y Publicidad, D.F: México.

Dirección General de Estadística. (1933-1970). Censos Industriales de 1930-1970. Departamento Autónomo de Prensa y Publicidad, D.F: México.

Dirección Nacional de Estadística / INEGI. (1923-1994). Anuarios Estadísticos de Comercio Exterior. Departamento Autónomo de Prensa y Publicidad / INEGI.

Dirección Nacional de Irrigación. (1931). La industria eléctrica en México, Estudios estadísticos preliminares, México, Editorial Cultura. 
Energising Mexico:

Historical Energy Consumption, Transitions and Economic Growth 1880-2015.

Instituto Nacional de Geografía, Estadística e Información (1994). Estadísticas Históricas de México. Talleres Gráficos del Instituto Nacional de Geografía, Estadística e Información, Aguascalientes: México.

Secretaría de Energía. (2020). Sistema de Información Energética. http://sie.energia.gob.mx/bdiController.do?action=cuadro\&subAction=exportar

Silíceo, M. (1857). Memoria de la Secretaría de Estado y del Despacho de Fomento, Colonización e Industria y Comercio de la República Mexicana. Imprenta de Vicente García Torres.

\section{ii. Articles and Books}

Aghion, P. \& Howitt. P. (1992). A model of growth through creative destruction. Econometrica, Vol. 60, pp. 323-351.

Allen, R.C. (2009). The British Industrial Revolution in Global Perspective. Cambridge University Press: New York.

Ang, B.W. (2005). The LMDI approach to decomposition analysis: a practical guide. Energy Policy. Vol. 33, pp. 867-871.

Ang, B.W. (2015). LMDI decomposition approach: A guide for implementation. Energy Policy. Vol. 86, pp. 233-238.

Bairoch, P. (1985). De Jéricho à Mexico: Villes et économie dans l'histoire, Paris: Gallimard.

Bertoni, R. (2011). Energía y desarrollo: la restricción energética en Uruguay como problema, 1882-2000. Montevideo: Universidad de la República.

Bolt, J. \& van Zanden, J.L. (2020), Maddison style estimates of the evolution of the world economy. A new 2020 update. Maddison Project Database, version 2020

Challú, A. E. \& Gómez-Galvarriato, A. (2015). Mexico's real wages in the age of the great divergence, 1730-1930, Revista de Historia Económica / Journal of Iberian and Latin American Economic History. Vol. 33, No. 1. Pp. 83-122.

Dahmén, E (1950) Svensk industriell företagarverksamhet. Kausalanalys av den industriella utvecklingen 1919-1939. Del I-II. Industriens utredningsinstitut. Stockholm. 
Enflo, K., Kander, A., \& Schön, L. (2008). Identifying development blocks a new methodology, Journal of Evolutionary Economics, Springer, Vol. 18, No.1. Pp. 57-76.

FAO (2010). Guide to Good Farming Practices for Animal Production Food Safety. OIE.

Garza-Toledo, E., Malegoza, J., de la Garza, L., Laviada, E., Trujillo, M., Sánchez, V., Corral, R., Amezcua, H., Reyes, R., \& Rojo, G. (1994). Historia de la Industria Eléctrica en México, Tomo I y II. Universidad Autónoma Metropolitana.

Gómez-Galvarriato, A. (2016). Industria y Revolución: Cambio económico y social en el valle de Orizaba, México. México: Fondo de Cultura Económica.

Haber, S. (1989). Industry and Underdevelopment: The Industrialization of Mexico 1890-1940, California: Stanford University Press.

Henriques, S. (2009). Energy Consumption in Portugal 1856-2006, Napoli: ISSM-CNR.

Henriques, S, (2011). Energy Transitions, Economic Growth and Structural Change: Portugal in a Long-run Comparative Perspective, Lund Studies in Economic History.

Henriques, S. T., \& Kander, A. (2010). The modest environmental relief resulting from the transition to a service economy. Ecological Economics. Vol. 70, No 2, Pp. 271-282.

Kander, A. (2002). Economic growth, energy consumption and CO2 emissions in Sweden 18002000, Lund Studies in Economic History.

Kander, A. (2005). Baumol's disease and dematerialization of the economy. Ecological Economics. Vol. 55, No. 1. Pp. 119-130.

Kander, A. Gales, B. Rubio, M. \& Malanima, P. (2007). North versus South: Energy transition and energy intensity in Europe over 200 years, European Review of Economic History. Vol. 11. No.2

Kander, A., Malanima, P., \& Warde, P. (2013). Power to the people: energy in Europe over the last five centuries. Princeton, NJ: Princeton University Press.

Maddison, A. (2007). Contours of the world economy, 1-2030 AD: Essays in macroeconomic history. Oxford: Oxford University Press. 
Energising Mexico:

Historical Energy Consumption, Transitions and Economic Growth 1880-2015.

Malanima, P (2001). The energy basis for early modern growth 1650-1820, p 53 in M. Prak (ed.), Early modern capitalism. Economic and social change in Europe 1400-1800, US: Routledge.

Malanima, P. (2006). Energy consumption in Italy, 1861-2000, CNR.

Masera, O. R. (1993). Sustainable Fuelwood Use in Rural Mexico. Vol. I: Current Patterns of Resource Use. Berkeley: Lawrence Berkeley Laboratory, US Dept. of Energy.

Morales-Moreno, H. (2010). Haciendas, molinos y camino a la fábrica en los orígenes de la industria mexicana (historia económica y arqueología industrial). Boletín De Monumentos Históricos, Tercera Época, no. 18, enero-abril.

Ortiz-Hernández, L., Delgado-Sánchez, G., \& Hernández-Briones, A. (2006). Cambios en factores relacionados con la transición alimentaria y nutricional en México. Gaceta médica de México, Vol. 142, No. 3. Pp. 181-193.

Romer, P.M. (1986). Increasing Returns and Long Run Growth. Journal of Political Economy, Vol. 94, Pp. 1002-1037.

Rubio, M. (2006). The role of Mexico in the first world oil shortage: 1918-1922, an international perspective. Revista De Historia Económica / Journal of Iberian and Latin American Economic History, Vol 24. No. 1. Pp. 69-95.

Solow, R. (1956). A contribution to the theory of economic growth. The Quarterly Journal of Economics. Vol. 70, No. 1, Pp. 65-94.

Smil, V. (2015). Natural Gas Fuel of the $21^{\text {st }}$ Century. US. Wiley.

Solow, R. (1974). Intergenerational Equity and Exhaustible Resources, Review of Economic Studies. Vol. 41, No. 5. Pp. 29-45.

Swan, T.W. (1956). Economic growth and capital accumulation. Economic Record. Vol. 32 No. 2. Pp. 334-361.

Warde, P. (2007). Energy consumption in England and Wales, 1560-2000. CNR.

Warde, P. (2019). Firewood consumption and energy transition: a survey of sources, methods and explanations in Europe and North America. Historia Agraria, Vol. 77. Pp. 7-32. 


\section{Appendix 1. Statistical series}

Energy consumption in Mexico, 188-2015. Petajoules.

\begin{tabular}{|c|c|c|c|c|c|c|c|c|c|c|}
\hline Year & Population & Food & Fodder & Wind and Water & Fuelwood & Coal & Oil & Natural Gas & $\begin{array}{l}\text { Primary } \\
\text { Electricity }\end{array}$ & Biogas \\
\hline 1880 & 10399000 & 28.5856863 & 6.42275717 & 0.0016 & 93.717872 & 0 & 0 & 0 & 0.014044643 & 0 \\
\hline 1881 & 10524000 & 28.9292973 & 8.24218519 & 0.0026 & 94.844397 & 0 & 0 & 0 & 0.016432233 & 0 \\
\hline 1882 & 10652000 & 29.281155 & 9.06640371 & 0.0029 & 95.9979587 & 0 & 0 & 0 & 0.019225712 & 0 \\
\hline 1883 & 10781000 & 29.6357615 & 9.97304408 & 0.0027 & 97.1605325 & 0 & 0 & 0 & 0.022494083 & 0 \\
\hline 1884 & 10912000 & 29.9958659 & 10.9703485 & 0.0011 & 98.3411308 & 0 & 0 & 0 & 0.026318078 & 0 \\
\hline 1885 & 11044000 & 30.3587191 & 12.0673833 & 0.0017 & 99.5307412 & 0 & 0 & 0 & 0.030792151 & 0 \\
\hline 1886 & 11178000 & 30.7270701 & 13.2741217 & 0.0019 & 100.738376 & 0 & 0 & 0 & 0.036026816 & 0 \\
\hline 1887 & 11313000 & 31.0981699 & 14.6015338 & 0.0018 & 101.955023 & 0 & 0 & 0 & 0.042151375 & 0 \\
\hline 1888 & 11450000 & 31.4747676 & 16.0616872 & 0.0040 & 103.189695 & 0 & 0 & 0 & 0.05058165 & 0 \\
\hline 1889 & 11589000 & 31.856863 & 17.6678559 & 0.0042 & 104.44239 & 0 & 0 & 0 & 0.050997253 & 0 \\
\hline 1890 & 11729000 & 32.2417074 & 19.4346415 & 0.0006 & 105.704098 & 0 & 0 & 0 & 0.468154779 & 0 \\
\hline 1891 & 11904000 & 32.7227628 & 21.3781057 & 0.0006 & 107.281234 & 3.99755664 & 0 & 0 & 0.524333352 & 0 \\
\hline 1892 & 12083000 & 33.2148137 & 23.5159163 & 0.0006 & 108.894417 & 6.99572412 & 0 & 0 & 0.587253355 & 0 \\
\hline 1893 & 12263000 & 33.7096135 & 25.8675079 & 0.0006 & 110.516614 & 5.19682363 & 0 & 0 & 0.657723757 & 0 \\
\hline 1894 & 12447000 & 34.2154089 & 28.4542587 & 0.0007 & 112.174858 & 5.99633496 & 0 & 0 & 0.736650608 & 0 \\
\hline 1895 & 12663000 & 34.8091687 & 31.2996845 & 0.0006 & 114.121494 & 5.39670146 & 0 & 0 & 0.898713742 & 0 \\
\hline 1896 & 12822000 & 35.2462419 & 34.429653 & 0.0006 & 115.554434 & 5.05898788 & 0 & 0 & 1.096430765 & 0 \\
\hline 1897 & 13014000 & 35.7740284 & 37.8726183 & 0.0010 & 117.284776 & 7.17701331 & 0 & 0 & 1.337645533 & 0 \\
\hline 1898 & 13209000 & 36.3100616 & 41.6598801 & 0.0000 & 119.042155 & 7.33937408 & 0 & 0 & 1.63192755 & 0 \\
\hline 1899 & 13406000 & 36.8515925 & 45.8258681 & 0.0006 & 120.817559 & 8.1775018 & 0 & 0 & 1.990951611 & 0 \\
\hline 1900 & 13607000 & 37.404119 & 50.408455 & 0.0005 & 120.956672 & 7.75480016 & 0 & 0 & 2.75385164 & 0 \\
\hline 1901 & 13755000 & 37.8109544 & 55.4493005 & 0.0007 & 122.272288 & 13.3918147 & 0.06 & 0 & 2.808928673 & 0 \\
\hline 1902 & 13904000 & 38.2205388 & 52.4587146 & 0.0006 & 123.596794 & 14.1844103 & 0.24 & 0 & 2.865107246 & 0 \\
\hline
\end{tabular}




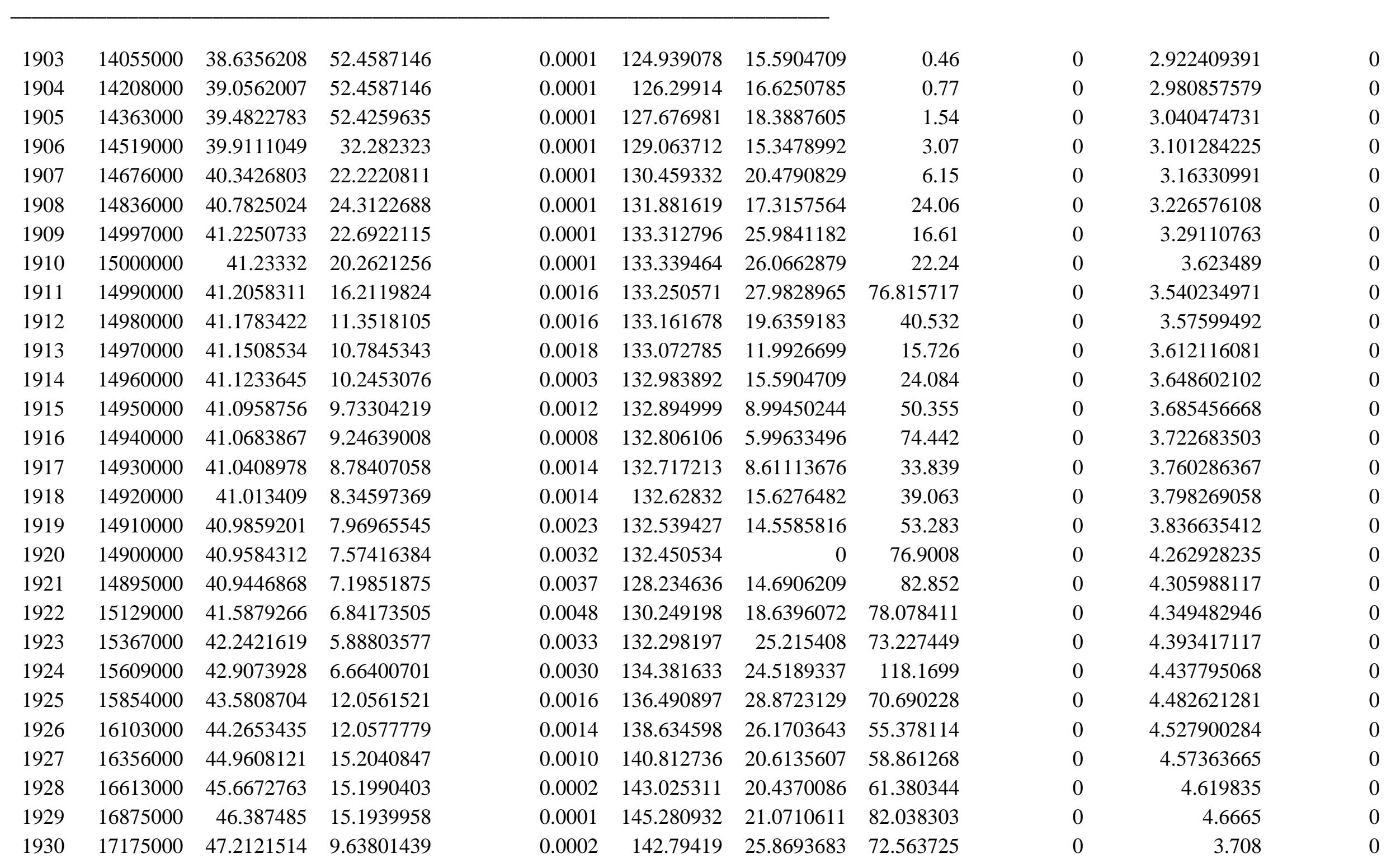




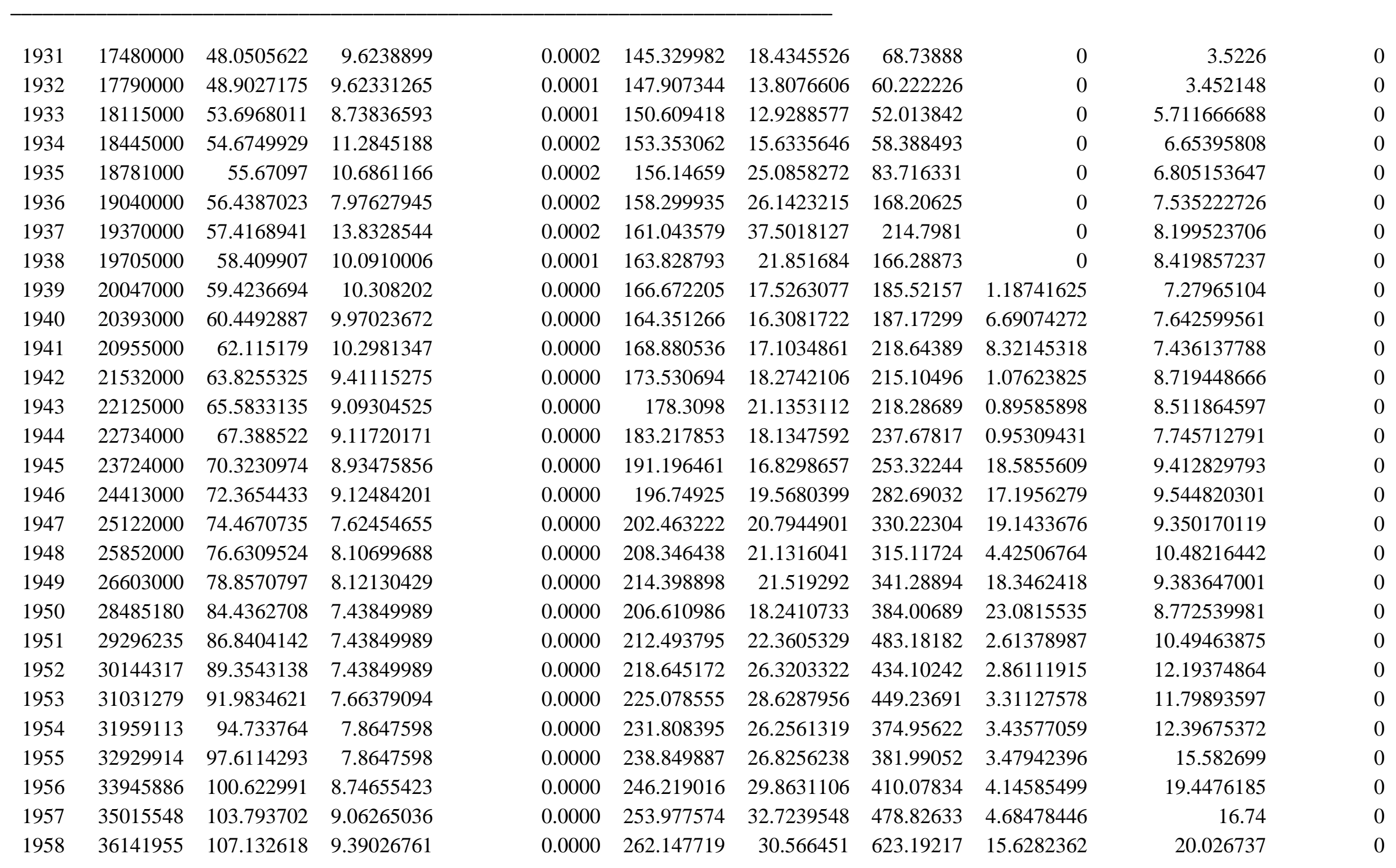




\begin{tabular}{|c|c|c|c|c|c|c|c|c|c|c|}
\hline 1959 & 37328466 & 110.649694 & 9.69048421 & 0.0000 & 270.753816 & 31.6985854 & 641.00607 & 10.72 & 21.8080575 & 0 \\
\hline 1960 & 38578505 & 114.355082 & 7.08962447 & 0.0000 & 289 & 35.4912873 & 659.21518 & 59.15 & 21.42088164 & 0 \\
\hline 1961 & 39836230 & 146.439051 & 6.97464455 & 0.0000 & 292 & 37.8003931 & 711.59645 & 62.7469833 & 21.15700632 & 0 \\
\hline 1963 & 42434264 & 155.989493 & 6.75894583 & 0.0000 & 298 & 43.0323073 & 717.54773 & 81.8544293 & 24.93950904 & 0 \\
\hline 1964 & 43774575 & 166.879602 & 6.65848997 & 0.0000 & 301 & 42.7250459 & 747.85117 & 82.3414994 & 29.29231746 & 0 \\
\hline 1965 & 45142399 & 172.094088 & 6.5631683 & 0.0000 & 181.711859 & 41.6548885 & 724.65141 & 511.662 & 35.64050652 & 0 \\
\hline 1968 & 49518803 & 200.01563 & 6.30990473 & 0.0000 & 190.761578 & 54.0749658 & 915.45494 & 601.569 & 52.33646826 & 0 \\
\hline 1969 & 51110928 & 206.446518 & 6.23713236 & 0.0000 & 193.881775 & 55.9204055 & 874.04115 & 635.803 & 55.49915088 & 0 \\
\hline 1970 & 52775158 & 213.168652 & 11.4701042 & 0.0000 & 196.504518 & 63.5713302 & 1029.616 & 398.713342 & 62.06836626 & 0 \\
\hline 1971 & 54406901 & 219.759565 & 0.56629685 & 0.0000 & 199.12079 & 42.9991355 & 1057.2352 & 390 & 60.1055343 & 0 \\
\hline 1972 & 55984294 & 238.921295 & 12.2551546 & 0.0000 & 201.783872 & 68.2816808 & 1092.2884 & 410 & 63.7235631 & 0 \\
\hline 1977 & 63759976 & 303.010946 & 14.0091929 & 0.0000 & 215.689499 & 71.7306882 & 1840.5323 & 489.999993 & 78.97433364 & 0 \\
\hline 1978 & 65295990 & 310.310652 & 14.4456272 & 0.0000 & 218.598332 & 69.2647327 & 2012.3044 & 620 & 66.91868262 & 0 \\
\hline 1979 & 66825878 & 317.581245 & 14.9164794 & 0.0000 & 221.552138 & 74.4014209 & 2234.3685 & 750 & 74.027961 & 0 \\
\hline 1980 & 68347479 & 324.812454 & 15.3617262 & 0.0000 & 223.415351 & 163.758263 & 2661.914 & 900 & 69.3036 & 0 \\
\hline 1981 & 69969263 & 332.519771 & 15.2610355 & 0.0000 & 224.442444 & 240.634698 & 2924.7029 & 970 & 121.3979305 & 0 \\
\hline 1982 & 71640904 & 345.638983 & 15.7508053 & 0.0000 & 225.478691 & 232.404996 & 3029.0381 & 1040 & 111.323667 & 0 \\
\hline 1983 & 73362881 & 353.94684 & 16.0451751 & 0.0000 & 226.524243 & 247.78247 & 2766.751 & 1050 & 99.0007235 & 0 \\
\hline 1984 & 75080138 & 362.231925 & 12.9885215 & 0.0000 & 227.582152 & 252.875725 & 2828.0894 & 1030 & 109.2335755 & 0 \\
\hline 1985 & 76767225 & 370.371451 & 13.4652396 & 0.0000 & 228.646792 & 270.253258 & 2951.66 & 1000 & 114.616692 & 0 \\
\hline 1986 & 78442430 & 378.453652 & 15.0677539 & 0.0000 & 229.721191 & 262.076432 & 2885.134 & 890 & 101.856258 & 0 \\
\hline
\end{tabular}




\begin{tabular}{|c|c|c|c|c|c|c|c|c|c|c|}
\hline 1987 & 80122492 & 374.83721 & 14.7806938 & 0.0000 & 230.805507 & 268.170215 & 3005.2988 & 900 & 97.654081 & 0 \\
\hline 1988 & 81781816 & 382.600029 & 14.4346801 & 0.0000 & 231.902919 & 245.295745 & 3065.6061 & 910 & 109.194652 & 0 \\
\hline 1989 & 83366836 & 390.015231 & 14.1404998 & 0.0000 & 233.007588 & 242.833678 & 3206.5989 & 880.561836 & 129.208285 & 0 \\
\hline 1991 & 86488032 & 404.617128 & 8.87056511 & 0.0000 & 278.695399 & 228.837403 & 3477.8193 & 962.008947 & 170.2454444 & 0 \\
\hline 1992 & 88111030 & 420.61998 & 9.74320921 & 0.0000 & 289.089174 & 231.727038 & 3516.1617 & 933.061243 & 183.1769586 & 0 \\
\hline 1993 & 89749141 & 428.439912 & 9.77399749 & 0.0000 & 277.80537 & 244.63495 & 3580.0209 & 1001.18067 & 199.5065917 & 0 \\
\hline 1996 & 94398579 & 450.635164 & 10.4791347 & 0.0000 & 280.207899 & 356.275327 & 3650.2963 & 1111.01946 & 363.1040005 & 0 \\
\hline 1997 & 95895146 & 459.756438 & 10.5697891 & 0.0000 & 281.181445 & 349.996238 & 3638.6871 & 1121.40367 & 375.0373286 & 0 \\
\hline 1998 & 97325063 & 466.611983 & 10.6151163 & 0.0000 & 282.32842 & 346.368629 & 3777.4261 & 1191.86844 & 355.7426828 & 0 \\
\hline 1999 & 98616905 & 472.805547 & 10.6377799 & 0.0000 & 283.591175 & 368.045748 & 3756.604 & 1231.82408 & 397.361925 & 0.002269 \\
\hline 2000 & 99926620 & 479.0848 & 10.6974909 & 0.0000 & 284.97633 & 393.355441 & 3712.5007 & 1202.83029 & 380.3888916 & 0.01576 \\
\hline 2005 & 106202903 & 509.175598 & 10.6974909 & 0.0000 & 266.433609 & 475.499025 & 4084.9042 & 1605.90081 & 456.5686797 & 0.688518 \\
\hline 2006 & 107449525 & 515.152361 & 10.6974909 & 0.0000 & 264.600482 & 462.03024 & 4119.0692 & 1745.50885 & 454.024553 & 0.675775 \\
\hline 2007 & 108700891 & 521.151867 & 10.6974909 & 0.0000 & 263.238403 & 531.198363 & 3995.0163 & 1694.71143 & 454.5448271 & 0.651122 \\
\hline 2008 & 109955400 & 527.166443 & 10.6974909 & 0.0000 & 262.048823 & 561.761402 & 3902.8497 & 1705.47851 & 482.9383228 & 0.808913 \\
\hline 2009 & 111212000 & 533.191043 & 10.6974909 & 0.0000 & 260.677582 & 657.048291 & 3867.567 & 1895.16503 & 437.521152 & 1.067139 \\
\hline 2010 & 113748671 & 545.352773 & 10.6974909 & 0.0000 & 259.310907 & 892.338834 & 3778.8003 & 1890.54773 & 412.8417804 & 1.298023 \\
\hline 2011 & 115367452 & 553.113801 & 10.6974909 & 0.0000 & 258.085751 & 1046.58331 & 3833.2842 & 1897.67372 & 470.165961 & 1.507667 \\
\hline 2012 & 116935670 & 560.632413 & 10.6974909 & 0.0000 & 256.742845 & 946.299621 & 3963.853 & 1843.31839 & 427.1635675 & 1.823098 \\
\hline 2013 & 118453929 & 567.911502 & 10.6974909 & 0.0000 & 255.422397 & 925.868751 & 3991.1161 & 1905.77089 & 456.8177267 & 1.972003 \\
\hline 2014 & 119936411 & 575.019064 & 10.6974909 & 0.0000 & 254.116775 & 838.476393 & 3948.9166 & 1866.61673 & 481.5559292 & 1.925703 \\
\hline
\end{tabular}


Energising Mexico:

Historical Energy Consumption, Transitions and Economic Growth 1880-2015.

$\begin{array}{lllllllllll}2015 & 121347800 & 581.785779 & 10.6974909 & 0.0000 & 252.840472 & 810.537222 & 3695.9441 & 1746.2678 & 497.7852988 & 1.867721\end{array}$

Energy and Product

\begin{tabular}{|c|c|c|c|}
\hline Year & $\begin{array}{l}\text { Energy per capita, } \\
\text { GJ }\end{array}$ & $\begin{array}{l}\text { Energy intensity } \\
\text { MJ/GDP }\end{array}$ & $\begin{array}{l}\text { Energy productivity } \\
\text { (efficiency) } \\
\text { 1990GK dollars per } \\
\text { GJ }\end{array}$ \\
\hline 1880 & 12.3802274 & 7.895553187 & 126.6535702 \\
\hline 1881 & 12.54607826 & 8.001325423 & 124.9792937 \\
\hline 1882 & 12.61430695 & 8.044838614 & 124.3033015 \\
\hline 1883 & 12.68848033 & 8.092143066 & 123.5766585 \\
\hline 1884 & 12.7689467 & 8.143460908 & 122.7979125 \\
\hline 1885 & 12.85669865 & 7.317415282 & 136.6602771 \\
\hline 1886 & 12.95200375 & 7.256024507 & 137.8165136 \\
\hline 1887 & 13.05565821 & 6.951894678 & 143.8456775 \\
\hline 1888 & 13.16861946 & 6.722113047 & 148.7627466 \\
\hline 1889 & 13.29038827 & 7.242718402 & 138.0697059 \\
\hline 1890 & 13.45802772 & 7.3864038 & 135.3838792 \\
\hline 1891 & 13.93687811 & 7.121552432 & 140.4188215 \\
\hline 1892 & 14.33491102 & 7.981576294 & 125.2885349 \\
\hline 1893 & 14.34794809 & 7.253765464 & 137.8594338 \\
\hline 1894 & 14.5881106 & 7.323348694 & 136.5495543 \\
\hline 1895 & 14.73002987 & 6.766205729 & 147.7933188 \\
\hline 1896 & 14.92640209 & 7.007700512 & 142.7001622 \\
\hline 1897 & 15.32557563 & 6.866297327 & 145.6389015 \\
\hline 1898 & 15.59417107 & 7.07860693 & 141.2707345 \\
\hline 1899 & 15.93794109 & 7.102469293 & 140.7961033 \\
\hline 1900 & 16.11512017 & 7.194250075 & 138.9998943 \\
\hline
\end{tabular}


Energising Mexico:

Historical Energy Consumption, Transitions and Economic Growth 1880-2015.

\begin{tabular}{rrrr}
\hline & & & \\
1901 & 16.85161367 & 7.837959848 & 127.5842208 \\
1902 & 16.65464484 & 7.815412876 & 127.9522932 \\
1903 & 16.72048211 & 8.343553945 & 119.8530035 \\
1904 & 16.7645041 & 8.353016492 & 119.7172304 \\
1905 & 16.88745673 & 8.537642433 & 117.1283534 \\
1906 & 15.3437844 & 7.203654646 & 138.8184261 \\
1907 & 15.18237723 & 6.838908664 & 146.2221604 \\
1908 & 16.28328427 & 7.055149164 & 141.7404476 \\
1909 & 16.21093481 & 6.757371741 & 147.9865306 \\
1910 & 16.4509846 & 6.446310582 & 155.1274931 \\
1911 & 19.94721881 & 7.847056967 & 127.436312 \\
1912 & 16.65135651 & 6.499358514 & 153.8613385 \\
1913 & 14.45161875 & 5.541264857 & 180.4642127 \\
1914 & 15.21897979 & 6.032096628 & 165.7798377 \\
1915 & 16.50569216 & 6.252156121 & 159.9448223 \\
1916 & 17.89040576 & 6.491438954 & 154.0490494 \\
1917 & 15.32177072 & 5.91574159 & 169.0405142 \\
1918 & 16.11783191 & 6.283755132 & 159.1405106 \\
1919 & 16.98024788 & 7.005052754 & 142.7540998 \\
1920 & 17.59396668 & 7.87907151 & 126.9185079 \\
1921 & 18.67943522 & 8.236082551 & 121.4169472 \\
1922 & 18.49105751 & 9.78362831 & 102.211569 \\
1923 & 18.43352684 & 8.900785534 & 112.3496343 \\
1924 & 21.21100868 & 9.747706196 & 102.5882377 \\
1925 & 18.68138318 & 8.125873503 & 123.0636927 \\
1926 & 17.45236901 & 7.14090385 & 140.038295 \\
1927 & 17.42645238 & 7.021133111 & 142.427153 \\
1928 & 17.47601231 & 7.049621747 & 141.8515824
\end{tabular}


Energising Mexico:

Historical Energy Consumption, Transitions and Economic Growth 1880-2015.

\begin{tabular}{rrrr}
\hline & & & \\
1929 & 18.64523994 & 7.254957174 & 137.8367888 \\
1930 & 17.57121564 & 6.86375611 & 145.6928224 \\
1931 & 16.80209575 & 6.136631025 & 162.9558622 \\
1932 & 15.95927817 & 5.665345463 & 176.5117426 \\
1933 & 15.66100452 & 5.506682322 & 181.5975467 \\
1934 & 16.26396102 & 5.424936964 & 184.3339391 \\
1935 & 18.00283013 & 5.982994394 & 167.1403873 \\
1936 & 22.30036141 & 7.138399939 & 140.0874157 \\
1937 & 25.44103963 & 8.089360772 & 123.619162 \\
1938 & 21.76554753 & 6.827336114 & 146.4700116 \\
1939 & 22.34344468 & 6.82034331 & 146.6201853 \\
1940 & 22.19316921 & 6.322840231 & 158.1567719 \\
1941 & 23.51700411 & 6.402669237 & 156.1848603 \\
1942 & 22.7541445 & 6.139812333 & 162.8714276 \\
1943 & 22.68095304 & 6.296766529 & 158.8116687 \\
1944 & 23.05952839 & 5.987932586 & 167.0025481 \\
1945 & 23.96750188 & 5.903325586 & 169.3960439 \\
1946 & 24.87356504 & 5.904003095 & 169.376605 \\
1947 & 26.43364011 & 6.003552148 & 166.5680543 \\
1948 & 24.9203337 & 5.536621573 & 180.6155589 \\
1949 & 26.00892388 & 5.783616606 & 172.9021939 \\
1950 & 25.71820913 & 5.445312117 & 183.6442023 \\
1951 & 28.17507052 & 5.86125869 & 170.6118178 \\
1952 & 26.2376356 & 5.375463143 & 186.0304821 \\
1953 & 26.35088713 & 5.148668842 & 194.22496 \\
1954 & 23.51291149 & 4.232747343 & 236.2531753 \\
1955 & 23.44993513 & 4.087490872 & 244.6488644 \\
1956 & 24.13027268 & 4.055508013 & 246.578233
\end{tabular}


Energising Mexico:

Historical Energy Consumption, Transitions and Economic Growth 1880-2015.

\begin{tabular}{rrrr}
\hline & & & \\
1957 & 25.69741294 & 4.190706612 & 238.6232425 \\
1958 & 29.55247452 & 4.594601138 & 217.6467488 \\
1959 & 29.36972299 & 4.430490721 & 225.7086321 \\
1960 & 30.73530344 & 4.471890505 & 223.6190709 \\
1961 & 32.09928579 & 4.643993894 & 215.3318938 \\
1962 & 32.10911787 & 4.425181624 & 225.9794252 \\
1963 & 31.29834928 & 4.119830102 & 242.7284561 \\
1964 & 31.4508621 & 4.03164493 & 248.037716 \\
1965 & 37.11581478 & 4.633106327 & 215.8379129 \\
1966 & 37.03147639 & 4.554356953 & 219.5699657 \\
1967 & 40.37535453 & 4.937673294 & 202.5245375 \\
1968 & 40.83003561 & 4.698508126 & 212.8335151 \\
1969 & 39.69761868 & 4.26535067 & 234.4473122 \\
1970 & 37.4563023 & 3.772414372 & 265.0822262 \\
1971 & 36.27088544 & 3.441913592 & 290.5360559 \\
1972 & 37.31559058 & 3.644100642 & 274.4161312 \\
1973 & 37.80004283 & 3.914668893 & 255.449446 \\
1974 & 41.19775301 & 4.213741742 & 237.3187683 \\
1975 & 42.80670595 & 4.374727231 & 228.5856803 \\
1976 & 44.20803979 & 4.762257868 & 209.9844292 \\
1977 & 47.28773607 & 5.108873819 & 195.7378544 \\
1978 & 50.73927914 & 5.519338534 & 181.1811314 \\
1979 & 55.19048685 & 5.87632952 & 170.1742553 \\
1980 & 63.81037702 & 6.579067637 & 151.9972214 \\
1981 & 69.03310923 & 6.897413122 & 144.9818914 \\
1982 & 69.82247489 & 6.803843447 & 146.975751 \\
1983 & 64.9134606 & 6.267091317 & 159.5636555 \\
1984 & 64.27126328 & 5.994889836 & 166.8087367
\end{tabular}


Energising Mexico:

Historical Energy Consumption, Transitions and Economic Growth 1880-2015.

\begin{tabular}{rrrr}
\hline & & & \\
1985 & 64.49768715 & 6.485469462 & 154.1908424 \\
1986 & 60.74683473 & 5.848634273 & 170.9800875 \\
1987 & 61.08963126 & 5.538325529 & 180.5599896 \\
1988 & 60.63965525 & 5.268030677 & 189.8242553 \\
1989 & 61.13181545 & 5.139631149 & 194.5664915 \\
1990 & 63.27446419 & 5.01644949 & 199.344178 \\
1991 & 63.95213359 & 5.089515805 & 196.4823449 \\
1992 & 63.36981028 & 5.011252408 & 199.5509144 \\
1993 & 63.9712242 & 5.000113031 & 199.9954789 \\
1994 & 65.22886173 & 4.909002544 & 203.7073705 \\
1995 & 65.45703482 & 4.793350025 & 208.6223612 \\
1996 & 65.9121923 & 4.613257987 & 216.7665461 \\
1997 & 65.03595048 & 4.428815479 & 225.7940085 \\
1998 & 66.11911857 & 4.46506732 & 223.960789 \\
1999 & 66.18034203 & 4.718071869 & 211.9509892 \\
2000 & 64.77176673 & 4.40705266 & 226.90902 \\
2001 & 64.89194921 & 4.266400343 & 234.3896305 \\
2002 & 70.49324939 & 4.507529215 & 221.8510302 \\
2003 & 66.10323754 & 4.2157677 & 237.2047207 \\
2004 & 63.57367528 & 4.009439662 & 249.4114102 \\
2005 & 69.77086019 & 4.334670737 & 230.69803 \\
2006 & 70.47047948 & 4.368095177 & 228.9327406 \\
2007 & 68.79451813 & 4.645738803 & 215.2510166 \\
2008 & 67.87703771 & 4.839031234 & 206.6529335 \\
2009 & 68.92334316 & 4.689524744 & 213.2412248 \\
2010 & 68.56555648 & 4.507926133 & 221.8314965 \\
2011 & 69.9759889 & 4.474454179 & 223.4909466 \\
2012 & 68.56030171 & 4.372468221 & 228.7037777
\end{tabular}


Energising Mexico:

Historical Energy Consumption, Transitions and Economic Growth 1880-2015.

\begin{tabular}{rrrr}
\hline & & & \\
2013 & 68.56787451 & 4.324411864 & 231.2453188 \\
2014 & 66.71411371 & 4.144763526 & 241.268288 \\
2015 & 63.02606104 & 3.906654748 & 255.9734772
\end{tabular}

